\title{
Digital Storytelling: Time to be Considered in Reading Comprehension
}

\author{
Esra’a Radaideh*, Dina Al-Jamal, Imad Sa’di \\ Department of Curricula and Methods of Instruction, Faculty of Education, Yarmouk University, Jordan
}

Received April 1, 2020; Revised April 23, 2020; Accepted May 27, 2020

Copyright $@ 2020$ by authors, all rights reserved. Authors agree that this article remains permanently open access under the terms of the Creative Commons Attribution License 4.0 International License

\begin{abstract}
This quasi-experimental study investigated the potential effect of digital storytelling of basic fifth grade students' reading comprehension skills. Thirty-four male and female fifth-grade students were randomly selected from a conveniently-selected school, namely; Al Rusol Educational School for excellence, a private school in Irbid Directorate of Education, Jordan. The participants were distributed randomly into two intact sections and thereby forming two groups: an experimental and a control. To achieve the aim of the study, a reading comprehension pre-test and post-test was developed. The reading comprehension test comprised two parts: the first part consists of one applied comprehension question and the second part is comprised of five analytic comprehension questions. Four stories in A Beautiful Mind 5 textbook from Units, 11, 12, 13 and 15 were redesigned digitally and then were showed by data show projector. The finding indicated that the experimental group outperformed the control group in the overall reading comprehension post-test and in each part of the test: applied and analytic comprehension. The study recommended using digital storytelling in teaching English language reading comprehension skills.
\end{abstract}

Keywords Digital Storytelling, Reading Comprehension Skills, Yarmouk University, Jordan

\section{Introduction}

Recently, people now either in their academic or personal lives use technology, for instance, to find specific information, to do their tasks and to communicate with each other. As such, English language classes are of no exceptions to the inclusion of digital technologies, so much so, to meet their needs in the globalization age. Within the context of communication, reading is very significant skill, as it develops cognitive and communicative skills as well by opening the doors for acquiring knowledge, values, cultural patterns, scientific facts, and of course language in a way that enlightening the minds of people.

Specifically, reading comprehension is defined as "the process of simultaneously extracting and constructing meaning through interaction and involvement with written language" (Snow, 2002:11). It consists of three elements: "the reader who is doing the comprehending, the text that is to be comprehended, and the activity in which comprehension is embedded". Similarly, Cain and Oakhill (2006) defined reading as a complex cognitive process that contains inferences, guessing meaning from a text and integrating information. Anderson (2012) stressed that reading comprehension is the core of language skills that enhances all other language skills and sub skills. Of course, this was earlier highlighted by Lyon (1997) who announced that reading gives individuals the opportunity to learn about science, mathematics, language arts, history and social studies.

Fundamentally, story is an old art and a worthy style of human being expression (Soleimani and Akbari, 2013). Grace (2011) defined storytelling as a united framework including a distinguished beginning, middle, and end, that provides details in which characters struggle through time, take action, experience emotions and discover meaning. Besides, Dujmović (2006) considered stories as authentic teaching methods in language classes as it helps students to get insight into human attitudes.

Equally, digital storytelling is the art of telling stories with various digital multimedia, such as: audio, images and video (Robin, 2008). Digital storytelling includes characteristics such as: interactivity, flexibility, community formation and universality (Park and Seo, 2009). In fact, digital storytelling has been marked as a distinguished strategy which helps teachers internalize lesson in a way to meet students' various needs (Figg, Gonsoulin and Mccartney, 2009). In digital storytelling, 
visual pictures and images with written text develop and facilitate students' comprehension (Burmark, 2004). According to Robin (2006), digital stories may be helpful in the discussion of the topics of the story and in making a conclusion or a summary.

In Jordan, English is taught from first to twelfth grade. It is taught to students three or four times a week, with 40 minutes for each session. English teachers are prepared with textbooks, CDs, computers, flash cards, games and others to facilitate their role in teaching the language.

According to the General and Specific Outcomes for English Language Teaching for Both Basic and Secondary Stages (GSO), fifth grade students are expected to understand and respond to written and simple English contexts. The GSO points out the general outcomes of fifth grade as follows: first, students should demonstrate recognition of simple words; second, students should utilize reading strategies to understand simple informational and reading materials; third, students have to show comprehending of simple knowledge and learning materials such as poems and stories; finally, students should also create relationships between their prior knowledge and experiences and reading materials.

Furthermore, the GSO elaborates the specific outcomes of the fifth grade students as follows: (1) Distinguish antonyms and synonyms; (2) Identify the meaning of new words; (3) Identify similarities and differences between events and characters; (4) Identify cause and effect; (5) Differentiate facts from opinion; (6) Identify the WH-questions information in a text. Finally, the GSO points out that grade fifth apply scanning strategy to locate specific information. As such, the present study will consider these outcomes and thereby transfer them into sub-skills.

Most of Jordanian EFL students have difficulty to determine which technique is more beneficial in reading comprehension and how it could be used effectively in classes (Alkhawwaldeh, 2011). Unfortunately, reading comprehension level is unsatisfactory, which may be due to the use of conventional method or the use of incorrect reading strategies in classes (Amoush, 2012). Furthermore, some Jordanian researchers (e.g., Al-Ansi, 1992; Al-Sarairah and Abul-Haija, 2007; Frahihat, 2003) indicated that EFL Jordanian students face problems while reading as contributed to the lack of proper instructional strategy. Therefore, using digital storytelling in education as a technique may have the potential of improving their language learning. Thus, the current study attempts to seek through identifying the potential effect of the digital storytelling on reading comprehension of fifth grade students in Jordan.

\subsection{Problem of the Study}

In light of the researcher's teaching experience, she noticed the following complaints in the English language reading classes. First, they face difficulties in understanding the context and get the information of the story. Second, most students are unable to figure out the purpose or message which the author tries to convey. Third, they may not have motivation to reading the English text. Correspondingly, some Jordanian researchers (e.g., Amoush, 2012; Jallad, 2006; Jarrah, 2008) believed that the reason behind students' failure to understand may be relevant to the absence of proper reading strategies. So, in order to overcome this problem, integrating digital storytelling as an instructional strategy may help students to improve their reading comprehension and may motivate them to read more effectively.

\subsection{Purpose of the Study}

The present study aims at investigating the effect of digital storytelling on fifth grade students' reading comprehension. Further, the study aims to assess such effect on their motivation.

\subsection{Question of the Study}

In order to achieve the aforementioned aims, the present study tries to answer the following question:

Are there any statistically significant differences (at $\alpha=$ 0.05) on fifth grade students' reading comprehension skills attributed to using the instructional technique (digital storytelling vs. conventional method)?

\subsection{Significance of the Study}

The study is significant as it may help EFL teachers, policy makers and curricula designers to plan and design appropriate activities and tasks that improve reading comprehension skills. Furthermore, this study is significant as it will foster students' motivation. Finally, it is significant for prospective researchers as it may fill in the research gap relevant to using technology in reading classes in Jordan.

\subsection{Definition of Terms}

The following terms will have the potential definitions in the present study as follows:

Storytelling: "a uniquely human experience that enables us to convey, through the language of words, aspects of ourselves and others, and the world real or imagined, that we inhabit” (Mcdrury and Alterio, 2002: 31). In this study, these stories will be presented in the classroom by the means of data show projector.

Digital Storytelling: "the act of using language and gesture in colorful ways to create scenes in sequence" (Gere, Kozolvich, and Kelin, 2002: 2). In this study, digital storytelling is defined as to convert all reading comprehension passages in A Beautiful Mind 5 into digital 
stories as endowed with audio, pictures, lyrics, music, colors and motions using digital technique and tools in presenting reading passages in textbook.

Reading Comprehension: "the process of simultaneously extracting and constructing meaning through interaction and involvement with written language" (Snow, 2002: 11). In this study, reading comprehension is defined as a process in which the student has the ability to interact between text and meaning not merely to decode letters and know the meaning of words. Specifically, it entails the following sub-skills: applying scanning strategy to locate specific information, distinguishing antonyms and synonyms, identifying the meaning of new words, identifying similarities and differences between events and characters, identifying cause and effect, differentiating facts from opinions. These sub-skills will be assessed by a pre-post reading comprehension test developed by the researcher.

\section{Theoretical Framework and Empirical Studies}

\subsection{Digital Storytelling}

Digital storytelling can be defined in several ways that revolve around common notions of using digital multimedia, such as images, video and audio to tell stories (e.g., Boase, 2008; Hett, 2012; İnceelli, 2005; Robin, 2006; Robin, 2009). Nowadays, digital storytelling is used as a new technological tool for teachers and students used in classrooms (Ohler, 2007). Many studies (e.g., Demirer, 2013; Kahraman, 2013; Sadik, 2008) pointed that digital storytelling improves motivation, students' achievement, learning strategies and enhances the learning environment, experiences and curriculum.

Moreover, it is reported that digital stories instruction are very effective for EFL learners' reading comprehension other than the traditional or paper-based instruction. In online digital stories instruction, students can freely and individually watch, listen, analyze, and practice some pre- reading activities such as questioning and explaining new words which enhance their reading comprehension ability (Shalkhord, Gorjian and Pazhakh, 2013).

\subsection{Reading Comprehension}

Reading is the most important receptive skill, among the four language skills, as it can enhance the whole language proficiency (e.g., Krashen and Brown, 2007; McDonough and Shaw, 1993; Snow, Burns and Griffin, 1998). Reading is defined as the integration of visual and cognitive processes to elicit the meaning from the content by comprehending the text, processing knowledge, and linking it to previous experience (Millrood, 2001). Of course, reading has purposes other than entertainment but also rather for language acquisition. Reading is considered as an essential for enhancing language skills of: writing, grammar, and vocabulary, (Harmer, 2007). In reading, readers may decode, anticipate, make analogy or even read sight word (Ehri, 1991).

Reading comprehension is achieved through three successive stages: the first stage is the pre-reading stage. In this stage, the aim is to prepare students for the reading lesson by activating their prior knowledge. The second stage is the during-reading stage. Here, students can read the text once or twice and analyze strategies which help them to deal with difficulties, to understand and to make sense of the reading. The third stage is the post-reading stage,where students can summarize, confirm, comment and evaluate (Goodman, 1998).

\subsection{Digital Storytelling and Reading}

Alshrari (2015) examined the effect of digital storytelling on EFL second intermediate students' reading skills in Saudi-Arabia. His study targeted fifty Saudi intermediate students who are divided into two groups: experimental and control group. A pre-test and post-test served as measuring instruments. The findings indicated that students of experimental group who received instruction by digital storytelling achieved more progress in reading comprehension tests than the control group who received instruction by traditional method.

Qoura (2016) examined the effect of digital stories in improving reading comprehension skills of the preparatory school students in Egypt. The participants of the study were classified into three groups and each group included thirty-five students: the first experimental group was taught by utilizing digital stories designed by the researcher. The second experimental group was taught by using digital stories downloaded from some educational sites on the internet. The control group was taught by using the traditional method of teaching reading skills. Instruments entailed a reading pre-post tests and a questionnaire. The results showed that utilizing digital stories enhanced preparatory school students' reading skills.

Apriltya, Régina and Arifin (2016) measured the effectiveness of the using digital story strategy on developing reading narrative text of the eighth grade students of SMP Negeri 2 Pontianak in Malaysia. Thirtyfive eighth students were the participants of the study. A pre-test and post-test were used as instruments. The results showed that using digital story has an effective impact on teaching reading narrative text.

Dewi (2017) looked into designing supplementary reading material utilizing integrated digital storytelling for the tenth grade students of SMA Negeri 1Cangkringan in Indonesia. Tenth grade students of SMA Negeri 1Cangkringan were the participants of the study. A 
questionnaire, interviews and observation served as measuring instruments. The findings showed that digital storytelling is appropriate and interesting strategy in teaching reading skills for tenth grade students of SMA Negeri 1Cangkringan.

Choo, Li, Redzuan and Shamsuddin (2017) investigated the effect of digital story on enhancing the students' comprehending of poem in Malaysian primary school. Twenty students who aged ten years old were selected as participants of the study. A pre-test, post-test, observation and interview served as measuring instruments. The findings indicated that students' performance and understanding of learning the poem were improved and their motivation was increased through using digital storytelling.

Hamdy (2017) explored the effect of using digital storytelling strategy on students' reading comprehension and listening comprehension. The design of this study was quasi-experimental and pre-post tests and observations were used to collect the data and assess participants' comprehension abilities before and after the treatment. The participants of the study consisted of 60 students of level II at Language Development Center of UIN Suska and were divided into an experimental and a control group. The results showed that the students at the experimental group outperformed their counterparts in the control group. So, the use of digital storytelling had a significant effect on students' reading and listening comprehension at Language Development Center of UIN Suska Riau.

Anggeraini and Afifah (2017) investigated the effect of digital storytelling as a teaching medium on reading classroom for English students at university of Baturaja. The participants of the study are the second semester students and English lecturer as English teaching experts. The researcher used research and development (R \&D) design that was developed by Borg and Gall in 1983. Data were collected by the means of questionnaire, observation, interviews and pre-post-tests. The results of the study showed that students' achievements was improved significantly and their interest was increased noticeably after applying digital storytelling for teaching reading of short stories.

Alkhlili (2018) examined the effectiveness of digital stories in improving reading comprehension skills of the preparatory school pupils. The researcher prepared two instruments: a questionnaire and a pre-post reading comprehension test. Their study adopted the descriptive method. The participants of the study consisted of 40 pupils who were divided into two groups: the first group was taught by digital storytelling strategy whereas the second group was taught by traditional method of teaching. The results revealed positive effect of digital stories on students' reading skills among first year preparatory school pupils.

Adıgüzel and Kumkale (2018) explored the effect of the digital stories on reading comprehension. The participants of the study were 34 fifth grade students at a private secondary school in Düzce,Turkey. Pre- post-test were used as data collection instruments. The findings showed that using digital stories in English lessons had a positive effect on the reading comprehension.

\section{Methods and Procedures}

\subsection{Participants}

Thirty-four male and female fifth-grade students were randomly selected from a conveniently-selected school, namely; Al Rusol Educational School for excellence, a private school in Irbid Directorate of Education, Jordan. The researcher selected this school, in particular, for three reasons: firstly, it was equipped with digital resources such as data show projector which aided the delivery of this study. Secondly, it teaches an English language textbook, namely; A Beautiful Mind 5, which introduces reading through stories. Thirdly, fifth-grade students in private school have better language levels than their counterparts in public school in terms of previous knowledge, using technology and educational level.

The participants were ten years old who have been studying English as a foreign language for five years; they were distributed randomly into two intact sections and thereby forming two groups: an experimental and a control. The control group (viz. 16 students) was taught by conventional method; whereas the experimental group (viz.18 students) was taught through using digital storytelling technique. The reason behind selecting fifth-grade students is that they are neither beginners nor advanced; entertainment techniques such as digital storytelling may have a positive impact on their learning.

\subsection{Design and Variables of the Study}

This study followed a quasi- experimental research design which entailed two variables; specifically, the independent variable is the instructional technique with two levels (i.e. digital storytelling technique vs. the conventional method), whereas, the dependent variables is students' scores on the reading comprehension post-test across six comprehension levels. Of course, this design uses a pre- post-test.

\subsection{Instruments}

\section{To achieve the aim of this study, one instrument was developed as follows:}

\section{The Reading Comprehension Test}

This test was developed to achieve the purpose of the study and was introduced before the treatment took place 
in order to find out whether the two groups were initially equivalent in terms of their reading comprehension levels. The same test was repeated once treatment is over in order to investigate the effect of the using digital storytelling on improving fifth grade students' reading comprehension in English language.

The General and Specific Outcomes for English Language Teaching for Both Basic and Secondary Stages (GSO) elaborates the specific outcomes of the fifth-grade students as follows: (1) distinguish antonyms and synonyms; (2) identify the meaning of new words; (3) identify similarities and differences between events and characters; (4) identify cause and effect; (5) differentiate facts from opinion; (6) identify the WH-questions information in a text. Finally, the GSO points out that the fifth-grade students apply scanning strategy to locate specific information. As such, the present study considered these outcomes and thereby transferred them into sub-skills.
The test consists of a reading passage followed by groups of questions. The test specifications are illustrated in Table 1.

Table 1 shows that the first part of the reading comprehension test consists of one applied comprehension question and the second part is comprised of five analytic comprehension questions. The test is out of 30 .

\section{Validity of the instruments}

In order to establish the face and content validity of the instrument (the reading comprehension test), a validation jury of ten university professors and one English language supervisor were consulted. The jury approved the test and gave insightful comments. One of their comments was the appropriateness of pictures with the purpose of the study. Furthermore, the content validity has been established by conducting the content analysis of textbook by the means of Table of specification (Table 1).

Table 1. Table of Specifications Concerning the Reading Comprehension Test

\begin{tabular}{|c|c|c|c|c|}
\hline \multirow{2}{*}{ Outcomes } & \multicolumn{3}{|c|}{ Bloom Levels } & \multirow{2}{*}{ Total points } \\
\hline & Application & Analysis & Evaluation & \\
\hline $\begin{array}{l}\text { Apply scanning strategy to locate specific information. } \\
\text { (question one with parts:1-9) }\end{array}$ & 9 & & & 9 \\
\hline $\begin{array}{l}\text { Distinguish antonyms and synonyms } \\
\text { (question two with parts: 1-6) }\end{array}$ & & 6 & & 6 \\
\hline $\begin{array}{l}\text { Identify the meaning of new words } \\
\text { (question three with parts: } 1-5 \text { ) }\end{array}$ & & 5 & & 5 \\
\hline $\begin{array}{l}\text { Identify similarities and differences between events and characters } \\
\text { (question four with parts: 1-2) }\end{array}$ & & 2 & & 4 \\
\hline $\begin{array}{l}\text { Identify cause and effect } \\
\text { (question five with parts: } 1-3 \text { ) }\end{array}$ & & 3 & & 3 \\
\hline $\begin{array}{l}\text { Differentiate facts from opinions } \\
\text { (question six with parts: } 1-3 \text { ) }\end{array}$ & & 3 & & 3 \\
\hline Total & & & & 30 \\
\hline
\end{tabular}


Table 2. Pearson Correlation Coefficient between the Item Score and the Total Score of Skill Measured by the Item for the Reading Comprehension Test

\begin{tabular}{|c|c|c|c|}
\hline Sub-skill & Item & Correlation Coefficient & Level of Significance \\
\hline \multirow{9}{*}{$\begin{array}{c}\text { Apply scanning strategy to locate specific } \\
\text { information }\end{array}$} & 1 & .523 & $<.05$ \\
\hline & 2 & .516 & $<.05$ \\
\hline & 3 & .517 & $<.05$ \\
\hline & 4 & .485 & $<.05$ \\
\hline & 5 & .463 & $<.05$ \\
\hline & 6 & .505 & $<.05$ \\
\hline & 7 & .633 & $<.05$ \\
\hline & 8 & .561 & $<.05$ \\
\hline & 9 & .495 & $<.05$ \\
\hline \multirow{6}{*}{ Distinguish antonyms and synonyms } & 10 & .466 & $<.05$ \\
\hline & 11 & .492 & $<.05$ \\
\hline & 12 & .500 & $<.05$ \\
\hline & 13 & .512 & $<.05$ \\
\hline & 14 & .499 & $<.05$ \\
\hline & 15 & .534 & $<.05$ \\
\hline \multirow{5}{*}{ Identify the meaning of new words } & 16 & .459 & $<.05$ \\
\hline & 17 & .444 & $<.05$ \\
\hline & 18 & .621 & $<.05$ \\
\hline & 19 & .499 & $<.05$ \\
\hline & 20 & .486 & $<.05$ \\
\hline \multirow{2}{*}{$\begin{array}{l}\text { Identify similarities and differences between } \\
\text { events and characters }\end{array}$} & 21 & .555 & $<.05$ \\
\hline & 22 & .521 & $<.05$ \\
\hline \multirow{3}{*}{ Identify cause and effect } & 23 & .455 & $<.05$ \\
\hline & 24 & .467 & $<.05$ \\
\hline & 25 & .489 & $<.05$ \\
\hline \multirow{3}{*}{ Differentiate facts from opinions } & 26 & .446 & $<.05$ \\
\hline & 27 & .502 & $<.05$ \\
\hline & 28 & .505 & $<.05$ \\
\hline
\end{tabular}

Further, the construct validity was evaluated by using the correlation analysis. As such, the reading comprehension test was piloted to a sample of 26 students from a sample outside the study where Pearson correlation coefficient was extracted between the item score and the total score of the skill measured per item. It is clear from Table 2 that Pearson Correlation Coefficient between the Item score and the total score of skill measured by the item for the Reading Comprehension Test are statistically significant (i.e., the values are higher than .35). Of course, this indicates an acceptable degree of internal consistency for reading comprehension test according to (Bryman and Cramer, 1997).

To find out the relationship between the total score for each reading comprehension skill and the total score for the reading comprehension test, the Pearson correlation coefficient was extracted. It is clear from Table 3 that correlation coefficients ranged from .444 to .852 all of which are statistically significant $(\mathrm{p}<.05)$, indicating that the test has an acceptable degree of internal consistency (construct validity) (Brown, 1983; Bryman and Cramer, 1997) .

Table 3. Pearson Correlation Coefficient between the Total Score of Sub-Skill and the Total Score of the Reading Comprehension Test

\begin{tabular}{ccc}
\hline Sub-skill & $\begin{array}{c}\text { Correlation } \\
\text { Coefficient }\end{array}$ & $\begin{array}{c}\text { Level of } \\
\text { Significance }\end{array}$ \\
\hline $\begin{array}{c}\text { Apply scanning strategy to locate } \\
\text { specific information }\end{array}$ & .852 & $<.05$ \\
\hline $\begin{array}{c}\text { Distinguish antonyms and } \\
\text { synonyms }\end{array}$ & .682 & $<.05$ \\
\hline $\begin{array}{c}\text { Identify the meaning of new words } \\
\text { Identify similarities and } \\
\text { differences between events and } \\
\text { characters }\end{array}$ & .717 & $<.05$ \\
\hline Identify cause and effect & .444 & $<.05$ \\
\hline Differentiate facts from opinions & .472 & $<.05$ \\
\hline
\end{tabular}




\section{Reliability of the test}

The reliability of the reading comprehension test was evaluated by using the Cronbach Alpha approach, and as shown in Table 3, the values of the Corrected Item-Total Correlation, all are above the cut-off score value which is .20, indicating that the reading comprehension test has an acceptable degree of stability and applicability (Doran, 1980).

Table 4. Corrected Item-Total Correlation for each Sub-Skill of Reading Comprehension Test.

\begin{tabular}{|c|c|c|c|}
\hline Sub-skill & Item & $\begin{array}{c}\text { Corrected Item-Total } \\
\text { Correlation }\end{array}$ & Sig. \\
\hline \multirow{9}{*}{$\begin{array}{l}\text { Apply scanning } \\
\text { strategy to locate } \\
\text { specific } \\
\text { information }\end{array}$} & 1 & .321 & $<.05$ \\
\hline & 2 & .432 & $<.05$ \\
\hline & 3 & .500 & $<.05$ \\
\hline & 4 & .253 & $<.05$ \\
\hline & 5 & .533 & $<.05$ \\
\hline & 6 & .333 & $<.05$ \\
\hline & 7 & .277 & $<.05$ \\
\hline & 8 & .298 & $<.05$ \\
\hline & 9 & .345 & $<.05$ \\
\hline \multirow{6}{*}{$\begin{array}{l}\text { Distinguish } \\
\text { antonyms and } \\
\text { synonyms }\end{array}$} & 10 & .458 & $<.05$ \\
\hline & 11 & .498 & $<.05$ \\
\hline & 12 & .436 & $<.05$ \\
\hline & 13 & .400 & $<.05$ \\
\hline & 14 & .503 & $<.05$ \\
\hline & 15 & .409 & $<.05$ \\
\hline \multirow{5}{*}{$\begin{array}{l}\text { Identify the } \\
\text { meaning of new } \\
\text { words }\end{array}$} & 16 & .408 & $<.05$ \\
\hline & 17 & .555 & $<.05$ \\
\hline & 18 & .325 & $<.05$ \\
\hline & 19 & .476 & $<.05$ \\
\hline & 20 & .632 & $<.05$ \\
\hline \multirow{2}{*}{$\begin{array}{c}\text { Identify } \\
\text { similarities and } \\
\text { differences } \\
\text { between events and } \\
\text { characters }\end{array}$} & 21 & .365 & $<.05$ \\
\hline & 22 & 376 & $<.05$ \\
\hline \multirow{3}{*}{$\begin{array}{c}\text { Identify cause and } \\
\text { effect }\end{array}$} & 23 & .467 & $<.05$ \\
\hline & 24 & .298 & $<.05$ \\
\hline & 25 & .475 & $<.05$ \\
\hline \multirow{3}{*}{$\begin{array}{l}\text { Differentiate facts } \\
\text { from opinions }\end{array}$} & 26 & .486 & $<.05$ \\
\hline & 27 & .498 & $<.05$ \\
\hline & 28 & .540 & $<.05$ \\
\hline
\end{tabular}

The Cronbach alpha coefficients for each sub-skill were extracted. As seen in Table 4, the Cronbach alpha coefficients for the apply scanning strategy to locate specific information, distinguish antonyms and synonyms, identify the meaning of new words, identify similarities and differences between events and characters, identify cause and effect, differentiate facts from opinions were $.77, .78, .76,73,79$, and .76 , respectively, and it was calculated to be .81 for the entire scale, and all areabove the cut-off value .70 (Cronbach, 1951).

Further, the reading comprehension test was re-administered to the pilot sample after two weeks after the first administration. Table 6 shows the Pearson correlation coefficient between the two applications. As seen in Table 4, the test-retest coefficients for the apply scanning strategy to locate specific information, distinguish antonyms and synonyms, identify the meaning of new words, identify similarities and differences between events and characters, identify cause and effect, differentiate facts from opinions were .82, .75, .71, 79, 79, and .83 , respectively, and it was calculated to be .84 for the entire scale, and all wereabove the cut-off value .70 (Odeh, 2010). With this in mind, reading comprehension test has acceptable level of reliability and can be used to measure reading comprehension skills.

Table 5. Cronbach Alpha Coefficients and Test-Retest Values for each Reading Comprehension Sub-Skill and Reading Comprehension Test

\begin{tabular}{ccc}
\hline Sub-Skill & $\begin{array}{c}\text { Alph } \\
\text { Coefficient }\end{array}$ & $\begin{array}{c}\text { Test -Retest } \\
\text { Value }\end{array}$ \\
\hline $\begin{array}{c}\text { Apply scanning strategy to } \\
\text { locate specific information }\end{array}$ & .77 & .82 \\
\hline $\begin{array}{c}\text { Distinguish antonyms and } \\
\text { synonyms }\end{array}$ & .78 & .75 \\
\hline $\begin{array}{c}\text { Identify the meaning of new } \\
\text { words }\end{array}$ & .76 & .71 \\
\hline $\begin{array}{c}\text { Identify similarities and } \\
\text { differences between events } \\
\text { and characters }\end{array}$ & .73 & .79 \\
\hline $\begin{array}{c}\text { Identify cause and effect } \\
\text { opinions }\end{array}$ & .79 & .7 .9 \\
\hline $\begin{array}{c}\text { Differentiate facts from } \\
\text { Entire Scale }\end{array}$ & .78 & .83 \\
\hline
\end{tabular}

\section{Item difficulty and item discrimination Indices for the reading comprehension test}

The different levels of Item Difficulty (IDEF) and Item Discrimination (IDES) use the following formulas:

$I D E F=$ (total scores of the item)/ (students number)*(item score)

IDES = (sum of marks obtained from the upper category sum of marks obtained from the lower category)/(the number of students in one of the two category)* (item score)

Table 6 shows the item difficulty and item discrimination of the reading comprehension test. From Table 6 it is clear that the item discrimination indices of the reading comprehension test items ranged from .445 to .670, all of which are of high discrimination (greater than .20) (Brown, 1983). The difficulty levels ranged from .309 to .570 , and where Doran (1980) indicates that any item within the distribution of difficulty indices from .20 to .80 could be acceptable, and therefore the reading comprehension test clauses have an acceptable 
degree of difficulty and discrimination indices.

Table 6. Summary Results of Item Difficulty and Item Discrimination Indices for the Reading Comprehension Test

\begin{tabular}{|c|c|c|}
\hline Item Difficulty & $\begin{array}{c}\text { Item } \\
\text { Discrimination }\end{array}$ & Item No. \\
\hline .474 & .445 & 1 \\
\hline .500 & .538 & 2 \\
\hline .444 & .506 & 3 \\
\hline .520 & .438 & 4 \\
\hline .437 & .507 & 5 \\
\hline .316 & .503 & 6 \\
\hline .474 & .546 & 7 \\
\hline .500 & .547 & 8 \\
\hline .444 & .610 & 9 \\
\hline .520 & .599 & 10 \\
\hline .437 & .521 & 11 \\
\hline .316 & .507 & 12 \\
\hline .329 & .503 & 13 \\
\hline .376 & .546 & 14 \\
\hline .312 & .547 & 15 \\
\hline .309 & .610 & 16 \\
\hline .312 & .599 & 17 \\
\hline .430 & .521 & 18 \\
\hline .544 & .507 & 19 \\
\hline .442 & .595 & 20 \\
\hline .375 & .429 & 21 \\
\hline .503 & .430 & 22 \\
\hline .570 & .601 & 23 \\
\hline .377 & .670 & 24 \\
\hline .394 & .613 & 25 \\
\hline .519 & .553 & 26 \\
\hline .375 & .459 & 27 \\
\hline .474 & .595 & 28 \\
\hline
\end{tabular}

\subsection{The Digital Material of Lesson Plans}

To achieve the objectives of the study, the researcher redesigned the stories in the textbook under the study, and then lesson plans were developed accordingly. The teaching materiel was taken from Unites, 11, 12, 13 and 15 of A Beautiful Mind 5 (namely, The Owl and the Pigeons, The Wolves of the sea, Octopus and Ants are Extremely Social Creatures). These unites were redesigned in a digital way that suits teaching with digital storytelling mediation. Lesson plans consist of digital stories (pictures, motions, colors, music, lyrics and audio) reading texts, Learner's Book, Activity Book, work sheets, white board, flash cards, marked pen, data show projector, real objects, videos, songs.

These lesson plans were developed to teach reading comprehension by digital storytelling to Jordanian EFL Fifth-grade students. These lesson plans aim at allowing the teachers to help their students in enhancing their reading comprehension throughout the second semester of the academic year 2019-2020. Furthermore, digital storytelling technique may help students to work cooperatively, communicate and exchange their ideas and experiences, which may result in enhanced motivation.

Lessons plans had four-weeks which started in February 2020 and ended in March 2020. The researcher redesigned the reading texts of Unites, 11, 12, 13 and 15 of the Student Book, so that the teacher/researcher taught them by using digital storytelling following the process approach, with its three stages, which the researcher followed in teaching reading, each reading text was covered in one week (i.e. five teaching days).

\section{Content Validity of the Lesson Plans}

The content validity of the lesson plans was obtained by giving them to the same jury who validated the instruments of the study. The jury examined and approved the lesson plans. The received feedback was showed that the lesson plans were appropriate, clear and detailed enough to achieve the purpose of the study.

\section{Results and Discussion}

\section{Results pertinent to the research question}

The question of the study reads as: Are there any statistically significant differences at $(a=0.05)$ on fifth grade students reading comprehension attributed to using instructional technique (digital storytelling vs. conventional method)'?

To answer this question, the means and standard deviations of student's performance in experimental and control groups for the sixth sub-skills of reading comprehension were extracted. Table 7 illustrates the means and standard deviations of sixth sub-skills of reading comprehension for the experimental group and control group in the pre-test and post-test of reading comprehension test. 
Table 7. Summary Results of Means and Standard Deviation of Reading Comprehension Sub-Skills for the Pre-Test and Post-Test

\begin{tabular}{|c|c|c|c|c|c|}
\hline \multirow{2}{*}{ Reading Sub-Skills } & \multirow{2}{*}{ Group } & \multicolumn{2}{|c|}{ Pre- test } & \multicolumn{2}{|c|}{ Post-test } \\
\hline & & Mean & Std. Deviation & Mean & Std. Deviation \\
\hline \multirow{2}{*}{$\begin{array}{l}\text { Apply scanning strategy to locate } \\
\text { specific information }\end{array}$} & Experimental & 5.333 & 1.414 & 7.389 & .778 \\
\hline & Control & 3.375 & 1.088 & 5.688 & 1.079 \\
\hline \multirow{2}{*}{ Distinguish antonyms and synonyms } & Experimental & 3.222 & 1.309 & 4.389 & .502 \\
\hline & Control & 2.313 & .946 & 3.313 & 1.302 \\
\hline \multirow{2}{*}{ Identify the meaning of new words } & Experimental & 3.389 & .850 & 4.944 & .802 \\
\hline & Control & 2.250 & .683 & 3.188 & .981 \\
\hline \multirow{2}{*}{$\begin{array}{l}\text { Identify similarities and differences } \\
\text { between events and characters }\end{array}$} & Experimental & 1.167 & .383 & 3.667 & .485 \\
\hline & Control & .875 & .500 & 2.563 & .512 \\
\hline \multirow{2}{*}{ Identify cause and effect } & Experimental & 1.778 & .548 & 2.611 & .502 \\
\hline & Control & 1.313 & 602 & 1.750 & .775 \\
\hline \multirow{2}{*}{ Differentiate facts from opinions } & Experimental & 1.000 & .840 & 2.611 & .502 \\
\hline & Control & .813 & .981 & 1.500 & .632 \\
\hline
\end{tabular}

It is clear from Table 7 that there are noticeable differences between the mean scores of experimental group performance and the mean scores of control group performance in favour of the experimental group in the sixth reading comprehension skills as measured by reading comprehension. In other words, the mean scores of experimental group performance are higher than the mean scores of the control group in the sixth reading comprehension skills.

To investigate the significance of the performance differences of the two groups in the sixth reading comprehension skills, a one way multivariate analysis of covariance (MANCOVA) was conducted to investigate the effects of instructional strategy (digital storytelling vs. conventional method) in the combined sixth reading comprehension skills, after controlling the effect of the pre-test scores. In order to evaluate multivariate significance, Hotelling's Trace statistic was used. The results indicated a statistical significant effect of instructional strategy (digital storytelling vs. conventional method) on the combined reading comprehension sub-skills $(F=15.040$, Hotelling's Trace $=4.297$, partial Eta square $=0.811, P<0.05$ ). The partial eta squared value of 0.994 represented that $81.1 \%$ of the variance in the combined variable (the sixth reading comprehension sub-skills together) could be explained by instructional strategy.

Further, in order to investigate on reading comprehension sub-skill, students in experimental group and control group significantly differed in their reading comprehension performance, Univariate analysis was conducted to investigate the effects of instructional on student's performance in the fourth reading sub-skills. Table 8 shows that students in experimental and control groups are differ in their reading comprehension performance in applying scanning strategy to locate specific information, distinguishing antonyms and synonyms, identifying the meaning of new words, identifying similarities and differences between events and characters, identifying cause and effect, and differentiating facts from opinions. As such, digital storytelling technique enhanced student's performance in applying scanning strategy to locate specific information, distinguishing antonyms and synonyms, identifying the meaning of new words, identifying similarities and differences between events and characters, identifying cause and effect, and differentiating facts from opinions.

To investigate the effect size of instructional strategy on student's reading comprehension sub-skills performance in applying scanning strategy to locate specific information, distinguishing antonyms and synonyms, identifying the meaning of new words, identifying similarities and differences between events and characters, identifying cause and effect, and differentiating facts from opinions, partial eta squared values were extracted and employed. The partial eta squared values were .334, .351, .694, .574, .433, and .418 for applying scanning strategy to locate specific information, distinguishing antonyms and synonyms, identifying the meaning of new words, identifying similarities and differences between events and characters, identifying cause and effect, and differentiating facts from opinions. This means that instructional strategy explained $33.4 \%$, $35.1 \%, 69.4 \%, 57.4 \%, 40.3 \%$, and $41.8 \%$ of the variance in the sixth reading comprehension sub-skills. 
Table 8. Results of MANCOVA Analysis for the Effect of Instructional Strategy on Student's Performance in Reading Comprehension Sub-Skills after Condoling the Effect of Pre-Test Scores

\begin{tabular}{|c|c|c|c|c|c|c|c|}
\hline Source & Reading Sub-Skills & $\begin{array}{c}\text { Type III Sum } \\
\text { of Squares }\end{array}$ & Df & Mean Square & $\mathbf{F}$ & Sig. & $\begin{array}{l}\text { Partial Eta } \\
\text { Squared }\end{array}$ \\
\hline \multirow{6}{*}{ Strategy } & $\begin{array}{c}\text { Apply scanning strategy to locate specific } \\
\text { information }\end{array}$ & 12.857 & 1 & 12.857 & 13.041 & $<.05$ & .334 \\
\hline & Distinguish antonyms and synonyms & 11.127 & 1 & 11.127 & 14.070 & $<.05$ & .351 \\
\hline & Identify the meaning of new words & 29.206 & 1 & 29.206 & 58.849 & $<.05$ & .694 \\
\hline & $\begin{array}{l}\text { Identify similarities and differences between } \\
\text { events and characters }\end{array}$ & 8.274 & 1 & 8.274 & 35.067 & $<.05$ & .574 \\
\hline & Identify cause and effect & 7.220 & 1 & 7.220 & 19.835 & $<.05$ & .433 \\
\hline & Differentiate facts from opinions & 6.546 & 1 & 6.546 & 18.637 & $<.05$ & .418 \\
\hline \multirow{6}{*}{ Error } & $\begin{array}{l}\text { Apply scanning strategy to locate specific } \\
\text { information }\end{array}$ & 25.634 & 26 & .986 & & & \\
\hline & Distinguish antonyms and synonyms & 20.562 & 26 & .791 & & & \\
\hline & Identify the meaning of new words & 12.903 & 26 & .496 & & & \\
\hline & $\begin{array}{c}\text { Identify similarities and differences between } \\
\text { events and characters }\end{array}$ & 6.135 & 26 & .236 & & & \\
\hline & Identify cause and effect & 9.463 & 26 & .364 & & & \\
\hline & Differentiate facts from opinions & 9.132 & 26 & .351 & & & \\
\hline \multirow{6}{*}{ Total } & $\begin{array}{l}\text { Apply scanning strategy to locate specific } \\
\text { information }\end{array}$ & 1528.000 & 34 & & & & \\
\hline & Distinguish antonyms and synonyms & 552.000 & 34 & & & & \\
\hline & Identify the meaning of new words & 628.000 & 34 & & & & \\
\hline & $\begin{array}{l}\text { Identify similarities and differences between } \\
\text { events and characters }\end{array}$ & 355.000 & 34 & & & & \\
\hline & Identify cause and effect & 185.000 & 34 & & & & \\
\hline & Differentiate facts from opinions & 169.000 & 34 & & & & \\
\hline \multirow{6}{*}{ Corrected Total } & $\begin{array}{l}\text { Apply scanning strategy to locate specific } \\
\text { information }\end{array}$ & 52.235 & 33 & & & & \\
\hline & Distinguish antonyms and synonyms & 39.529 & 33 & & & & \\
\hline & Identify the meaning of new words & 51.529 & 33 & & & & \\
\hline & $\begin{array}{l}\text { Identify similarities and differences between } \\
\text { events and characters }\end{array}$ & 18.265 & 33 & & & & \\
\hline & Identify cause and effect & 19.559 & 33 & & & & \\
\hline & Differentiate facts from opinions & 20.735 & 33 & & & & \\
\hline
\end{tabular}

Table 9. Adjusted and Unadjusted Group Means and Variability for Reading Sub-Skills Using Pre-Test Scores as a Covariate

\begin{tabular}{cccccc}
\hline \multirow{2}{*}{ Reading Sub-Skills } & \multirow{2}{*}{ specific information Group } & \multicolumn{2}{c}{ Adjusted Means } & \multicolumn{2}{c}{ Unadjusted Means } \\
\cline { 2 - 6 } Apply scanning strategy to locate & & Mean & S.E & Mean & Std \\
\cline { 2 - 6 } & Experimental & 7.398 & .282 & 7.389 & .778 \\
\hline \multirow{2}{*}{ Distinguish antonyms and synonyms } & Control & 5.677 & .304 & 5.688 & 1.078 \\
\cline { 2 - 6 } & Experimental & 4.636 & .252 & 4.389 & .5012 \\
\hline \multirow{2}{*}{\begin{tabular}{c} 
Identify the meaning of new words \\
\cline { 2 - 6 }
\end{tabular}} & Control & 3.034 & .273 & 3.313 & 1.302 \\
\hline \multirow{2}{*}{$\begin{array}{c}\text { Identify similarities and differences } \\
\text { between events and characters }\end{array}$} & Experimental & 5.339 & .200 & 4.944 & .802 \\
\hline \multirow{nyyyyy}{*}{ Identify cause and effect } & Control & 2.744 & .216 & 3.188 & .981 \\
\cline { 2 - 6 } & Experimental & 3.797 & .138 & 3.667 & .485 \\
\hline \multirow{2}{*}{ Differentiate facts from opinions } & Control & 2.416 & .149 & 2.563 & .512 \\
\cline { 2 - 6 } & Experimental & 2.813 & .171 & 2.611 & .502 \\
\hline
\end{tabular}


Furthermore, adjusted reading comprehension sub-skills mean for experimental and control groups have been extracted. Table 9 presents the means and standard deviations for experimental group and control group performance in reading comprehension sub-skills, before and after controlling for pre-test scores. As is evident from this table, virtually there are differences between experimental group and control group remains after differences in pre-test scores are controlled.

To investigate the effect of instructional technique on the combined reading comprehension sub-skills, mean scores and standard deviation of student's performance in experimental and control groups for the combined reading comprehension sub-skills were extracted. Table 10 illustrates the mean and standard deviation of the combined reading comprehension sub-skills for the experimental group and control group.

Table 10. Summary Results of Mean and Standard Deviation of the Combined Reading Comprehension Sub-Skills

\begin{tabular}{ccccc}
\hline \multirow{2}{*}{ Group } & \multicolumn{2}{c}{ Pre test } & \multicolumn{2}{c}{ Post test } \\
\cline { 2 - 5 } & Mean & $\begin{array}{c}\text { Std. } \\
\text { Deviation }\end{array}$ & Mean & $\begin{array}{c}\text { Std. } \\
\text { Deviation }\end{array}$ \\
\hline Experimental & 15.889 & 2.826 & 25.611 & 2.380 \\
\hline Control & 10.938 & 3.492 & 18.000 & 3.983 \\
\hline Total & 13.559 & 3.994 & 22.029 & 4.999 \\
\hline
\end{tabular}

It is clear from Table 10 that there is a noticeable difference between the mean scores of experimental group performance and the mean scores of control group performance in favour of the experimental group in the combined reading comprehension sub-skills, according to the instructional strategy (digital storytelling vs. conventional method). In other words, the mean scores of experimental group performance are higher than the mean scores of the control group in the combined reading comprehension sub-skills.

To test the significance difference in the combined reading comprehension sub-skills mean scores between experimental and control groups, after controlling the effect of pre-test scores, one way analysis of covariance (ANCOVA) was employed. Table 11 illustrates the summary results of ANCOVA.

Table 11. Results of ANCOVA Analysis for the Effect of Instructional Strategy on Student's Performance in the Combined Reading Comprehension Sub-Skills after Condoling the Effect of Pre-Test Scores

\begin{tabular}{|c|c|c|c|c|c|c|}
\hline Source & $\begin{array}{c}\text { Type III Sum } \\
\text { of Squares }\end{array}$ & Df & $\begin{array}{l}\text { Mean } \\
\text { Square }\end{array}$ & $\mathbf{F}$ & Sig. & $\begin{array}{c}\text { Partial } \\
\text { Eta } \\
\text { Squared }\end{array}$ \\
\hline Pre-test & 71.330 & 1 & 71.330 & 8.409 & $<.05$ & .213 \\
\hline Strategy & 508.122 & 1 & 508.122 & 59.905 & $5<.05$ & .659 \\
\hline Error & 262.948 & 31 & 8.482 & & & \\
\hline Total & 17325.000 & 34 & & & & \\
\hline $\begin{array}{c}\text { Corrected } \\
\text { Total }\end{array}$ & 824.971 & 33 & & & & \\
\hline
\end{tabular}

Table 11 shows that the mean scores of experimental group in the combined reading comprehension sub-skills aresignificantly higher than the mean scores of the control group. As such, digital storytelling technique enhanced student's performance in the combined reading comprehension sub-skills, and explained $65.9 \%$ of the variance in the combined reading comprehension sub-skills.

Furthermore, adjusted of the combined reading comprehension sub-skills mean for experimental and control groups have been extracted. Table 12 presents the means and standard deviations for experimental group and control group performance in the combined reading comprehension sub-skills, before and after controlling for pre-test scores. As is evident from this table, virtually there is difference between experimental group and control group and the combined reading comprehension sub-skills remains after differences in pre-test scores are controlled.

Table 12. Adjusted and Unadjusted Group Means and Variability for the Combined Reading Comprehension Sub-Skills Using Pre-Test Scores as a Covariate

\begin{tabular}{ccccc}
\hline \multirow{2}{*}{ Group } & \multicolumn{2}{c}{ Adjusted Means } & \multicolumn{2}{c}{ Unadjusted Means } \\
\cline { 2 - 5 } & Mean & S.E & Mean & STD \\
\hline Experimental & 26.713 & .785 & 25.611 & 2.380 \\
\hline Control & 16.760 & .844 & 18.000 & 3.983 \\
\hline
\end{tabular}

\section{Conclusions}

The following conclusions were drawn from the findings of the present study: (1) the digital storytelling technique was effective in enhancing reading comprehension skills; (2) there were statistically significant differences $(\mathrm{a}=0.05)$ which are evident in post-test mean scores in favour of the students of experimental group; (3)there is a positive and significant influence of digital storytelling on students' reading comprehension skills; (4) the digital storytelling technique increased students' participation in classroom activities; (5) the digital storytelling technique increased the interaction between the students and the teacher; (6) the digital storytelling technique added positive, interesting, motivational atmosphere to the classroom.

\section{REFERENCES}

[1] Adýgüzel, A., \& Kumkale, Z. (2018). The Effect of Digital Story Preparation Program on Reading Comprehension in English. Electronic Journal of Education Sciences, 7(14), (176-186).

[2] Al-Ansi, H. (1992). The Role of the Dictionary in Advanced EFL Learners' Vocabulary Build - up and Reading Comprehension (Master Thesis). Taiz University. Taiz, Yemen. 
[3] Alkhlili, M. (2018). Using Digital Stories for Developing Reading Skills of EFL Preparatory School Pupils. Multi-Knowledge Electronic Comprehensive Journal for Education and Science Publications, 4

[4] Alkhawwaldeh, A. (2011). EFL Reading Comprehension Interests among Jordanian High School Students and Their Relationship with Gender Achievement Level and Academic Stream. European Journal of Social Sciences, 232(3), 454-465.

[5] Al-Saraireh, B., \& Abul-Haija, K. (2007). An examination of Jordanian college-level students' use of reading strategies in reading Arabic (L1) and English (L2). Dirasat , 34(1), 213-225

[6] Alshrari, A. (2015). The Effect of Digital Storytelling on EFL Second Intermediate Students' Reading Skills in Saudi-Arabia. (Master Thesis). Yarmouk University, Saudi-Arabia.

[7] Amoush, K. (2012). The Effectiveness of Using Semantic Mapping Strategy on Reading Comprehension of Jordanian University Students. Interdisciplinary Journal of Contemporary Research in Business, 4(6), 714-729.

[8] Anderson, N. (2012). Reading Instruction. In A. Burns and J. C. Richards (Eds.). The Cambridge Guide to Pedagogy and Practice in Second Language Teaching. NewYork: Cambridge University Press.

[9] Anggeraini, Y., \& Afifah, N. (2017). Digital Storytelling as a Teaching Medium in Reading Classroom. Journal of Language and Literature12(1).

[10] Apriltya, R., \& Arifin, Z. (2016). The Use of Digital Story in Teaching Reading Narrative Text for SMP Students. Computer Science 5(4).

[11] Boase, K. (2008). Digital Storytelling for Reflection and Engagement: A Study of the Uses and Potential of Digital Storytelling. Retrieved on 8 May 2020 from https://gjamissen.files.wordpress.com/2013/05/boase_ assessment.pdf.

[12] Brown, F. (1983). Principles of Educational and Psychological Testing 3rd Ed. New York, NY: Holt, Rinehart \& Winston.

[13] Bryman, A., \& Cramer, D. (1997). Quantitative data analysis with SPSS for Windows: A guide for socialscientists. London, UK: Routledge.

[14] Burmark, L. (2004). Visual Presentations That Prompt, Flash \& Transform. Media and Methods, 40(6).

[15] Cain, K., \& Oakhill, J. (2006). Assessment Matters: Issues in the Measurement of Reading Comprehension. British Journal of Educational Psychology, 76(4), 697-708.

[16] Choo, Y., Li, K., Redzuan, N., \& Shamsuddin, S. (2017). Using Digital Story to Improve Primary School Pupils' Understanding of Poem. UNY Press, 228-239.

[17] Cronbach, L. (1951). Coefficient Alpha and the Internal Structure of Tests. Psychometrika, 16(3), 297-334.

[18] Dujmoviæ, M. (2006). Storytelling as a Method of EFL Teaching. Methodological Horizons, 1, 75-88.

[19] Demirer, V. (2013). Use of E-Storytelling in Primary
Education and its Effects. (Doctoral Thesis). Necmettin Erbakan University Institute of Educational Sciences, Konya, Turkey.

[20] Dewi, A. (2017). Designing Supplementary Reading Material using Integrated Digital Storytelling for the Tenth Grade Students of SMA Negeri 1Cangkringan. (Master Thesis). Sanata Dharma University, Yogyakarta, Indonesia.

[21] Doran, R. L. (1980). Basic Measurement and Evaluation of Science Education. Washingotn, DCl: National Science Teachers Association.

[22] Ehri, L. (1991). Development of the Ability to Read Words. In R. Barr, M. Kamil, P. Mosenthal, \& P. Pearson (Eds.), Handbook of Reading Research Volume II (pp. 383-417). New York: Longman.

[23] Figg, C., Mccartney, R., \& Gonsoulin, W. (2009). Differentiating Instruction with Digital Storytelling While Making Connections to Critical Literacy. Teaching and Learning, 5(1), (31-44).

[24] Frahihat, A. (2003). The effect of seen and unseen reading texts on the comprehension and reading strategies of tenth graders Irbid Second Directorate of Education (Doctoral Dissertation). Yarmouk University. Irbid, Jordan

[25] Gere, J., Kozolvich, B., \& Kelin II, D. (2002). By Word of Mouth: A Storytelling Guide fort The Classroom. Honolulu, HI: Pacific Resources for Education and Learning.

[26] Grace, P. (2011). The Effects of Storytelling on Worldview and Attitudes toward Sustainable Agriculture. Virginia: faculty of the Virginia Polytechnic Institute.

[27] Goodman, K. (1998). The Reading Process. In P. Carrell, J. Devine \& D. Heskey (Eds.), Interactive Approaches to Second Language Reading. (pp. 11-21). Cambridge: Cambridge University Press.

[28] Hamdy, M. (2017). The Effect of Using Digital Storytelling on Students' Reading Comprehension and Listening Comprehension. Journal of English and Arabic Language Teaching, 8(2), 112-123.

[29] Harmer, J. (2007). The Practice of English Language Teaching. Harlow, England: Pearson Education.

[30] Hett, K. (2012). Technology-Supported Literacy in the Classroom: Using Audiobooks and Digital Storytelling to Enhance Literacy Instruction. Illinois Reading Council Journal, 40(3), 3-13.

[31] Ýnceelli, A. (2005). The Elements of Digital Storytelling. The Turkish Online Journal of Educational Technology, 4(3), 132-142.

[32] Jallad, N. (2006). The Effect of Multiple Intelligences Strategies on EFL Ninth Graders' Achievement in Reading Comprehension (Doctoral Dissertation). Yarmouk Univeristy, Irbid, Jordan.

[33] Jarrah, N. (2008). The effect of the think aloud strategy on Jordanian eighth grade students' reading comprehension (Doctoral Dissertation). Yarmouk Univeristy, Irbid, Jordan.

[34] Kahraman, Ö. (2013). The Effect of Using Teaching Materials Prepared by Digital Storytelling Method at the 
Engagement Phase of Learning Cycle on Physics Course Achievement and Motivation Level (Doctoral Dissertation). Balikesir University Institute of Science, Balýkesir, Turkey.

[35] Krashen, S., \& Brown, C. (2007). What is Academic Language Proficiency? STETS Language and Communication Review, 6(1), 1-4.

[36] Lyon, R. (1997). Statement before the Committee on Education and Workforce. U.S. House of Representatives.

[37] McDonough, J., \& Shaw, C. (1993). Materials and methods in ELT. Oxford: Blackwell.

[38] McDrury, J., \& Alterio, M. (2002). Learning through Storytelling in Higher Education: Using Reflection and Experience to Improve Learning. London: Kogan page.

[39] Millrood, R. (2001). Teaching pronunciation: Modular Course in ELT Methodology. Retrieved from http://es.scribd.com/doc/139640911/2-Pronunciation on 15 February 2020.

[40] Odeh, S. (2010). Measurement and Evaluation in Instructional Process. Irbid: Dar Al-Amal.

[41] Ohler, J. (2007). Digital Storytelling in the Classroom: New Media Pathways to literacy, Learning and Creativity. Thousand Oaks, CA: Corwin Press.

[42] Park, E., \& Seo, J. (2009). Applying Digital Storytelling Technique to Website Navigation for Improving Emotional User Experience. Proceeding of the International Association of Societies of Design Research 2009, 4125-4128.

[43] Qoura, A. (2016). Using Digital Stories for Developing Reading Skills. Egyptian Association for Reading and Literacy, 180.

[44] Robin, B. (2008). Digital Storytelling: A Powerful Technology Tool for the 21st Century Classroom. Theory into Practice, 47, 220-228.

[45] Robin, B. (2006). The Educational Uses of Digital Storytelling. In Society for Information Technology \& Teacher Education International Conference 1(1), 709-716.

[46] Robin, B. (2009). Digital Storytelling: A Powerful Technology Tool for the 21st Century Classroom. Theory into Practice, 47(3), 220-228.

[47] Sadik, A. (2008). Digital Storytelling: A Meaningful Technology-Integrated Approach for Engaged Student Learning. Educational Technology Research and Development, 56(4), 487-506.

[48] Shalkhord, S., Gorjian, B., \& Pazhakh, A. (2013). The Effect of Digital Stories on Reading Comprehension: An Internet-Based Instruction for Iranian EFL Young Learners. International Journal of Language Learning and Applied Linguistics World, 4(4), 111- 124.

[49] Snow, C. (2002). Reading for Understanding toward an R\&D Program in Reading Comprehension. Santa Monica, CA : RAND,7.

[50] Snow, C., Burns, M., \& Griffin, P. (1998). Preventing Reading Difficulties in Young Children.Washington, DC: National Academy Press.
[51] Soleimani, H., \& Akbari, M. (2013). The Effect of Storytelling on Children's Learning English Vocabulary: A Case in Iran. International Research Journal of Applied \& Basic Sciences, 4(11), 4005-4014. 